\title{
OPTIMUM EARTHQUAKE RESPONSE OF TALL BUILDINGS
}

\author{
B.K Raghu Prasad ${ }^{1}$, Sajeet S.B ${ }^{2}$, Amarnath $K^{3}$ \\ ${ }^{1}$ Retd. Professor, Indian Institute of Science, Bangalore, Karnataka, India \\ ${ }^{2}$ Jr.Structural Engineering, Prasad Consultants, Karnataka, India \\ ${ }^{3}$ HOD, Civil Engineering Department, The Oxford College of Engineering, Karnataka, India
}

\begin{abstract}
The present study discusses the optimum earthquake response of tall buildings. The possibility of design approach is based on 'expendable top storey' for the tall buildings. If such a behaviour is feasible one can conceive of a structure whose top storey is permitted and designed to undergo large inelastic deformations while reducing damage in the lower storey. The concept was first proposed in an earlier research (Jagadish and Raghu Prasad). Such a concept juxtaposes the often-mentioned 'soft first storey' concept. The question is how to design a tall building so as to cause yielding of the uppermost floor or a few upper flowers, thus leaving the lower floor to be within the elastic limit? Recently observed that if a building has members size are derived for buildings designed for different values of $R$, it may be possible to optimize the energy absorption.
\end{abstract}

\section{INTRODUCTION}

In the present days, tall buildings are designed for earthquake resistance according to the earthquake zone they are in. They are designed for a known $\mathrm{R}$ value. The base shear increases as the $\mathrm{R}$ value decreases. So the zones where the Earth Quake is expected to be stronger, the building is designed for lesser $\mathrm{R}$ value, so as to allow for inelastic deformation (which is anyway inevitable) with provision of ductile detailing.

If the value of $\mathrm{R}$ is chosen to be small then the design base shear is larger and thus probability of the building yielding is less. In fact, it need not be provided with ductile detailing.

On the other hand if the value of $\mathrm{R}$ is higher, the design base shear is lower and thus the chances of the building getting into inelastic regime are higher thus requiring ductile detailing. In the present work, structural size and reinforcement required for different base shears or in other words different values of $\mathrm{R}$ are combined in one frame in such a way that yielding can take place in upper stories thus absorbing energy. The lower stories obviously will remain elastic. Such a building is found to consist of optimum sized members. Thus it can be called as optimum design. In other words the inelastic response can be termed optimum.

\section{R - Value}

With the "R" value located in the denominator of the calculation for the lateral load on the building, higher "R" value reduces the total load on the building. " $R$ " values range from 1.5 for unreinforced concrete and masonry shear walls to 8 for properly detailed shear walls, braced frames and moment frames.

High "R" value -> lower design lateral loads -> more ductile detailing expense.

low "R" value -> higher design lateral loads -> less ductile detailing expense.

\section{STRUCTURAL MODEL}

For this study, a nine storey building is considered. The dimensions in plan of the building are $48 \mathrm{mX} 20 \mathrm{~m}$. The structural models have the same story height of $3 \mathrm{~m}$. and have a uniform mass distribution over their height. Building plan is shown is below fig. $2.2 \mathrm{a}$ 


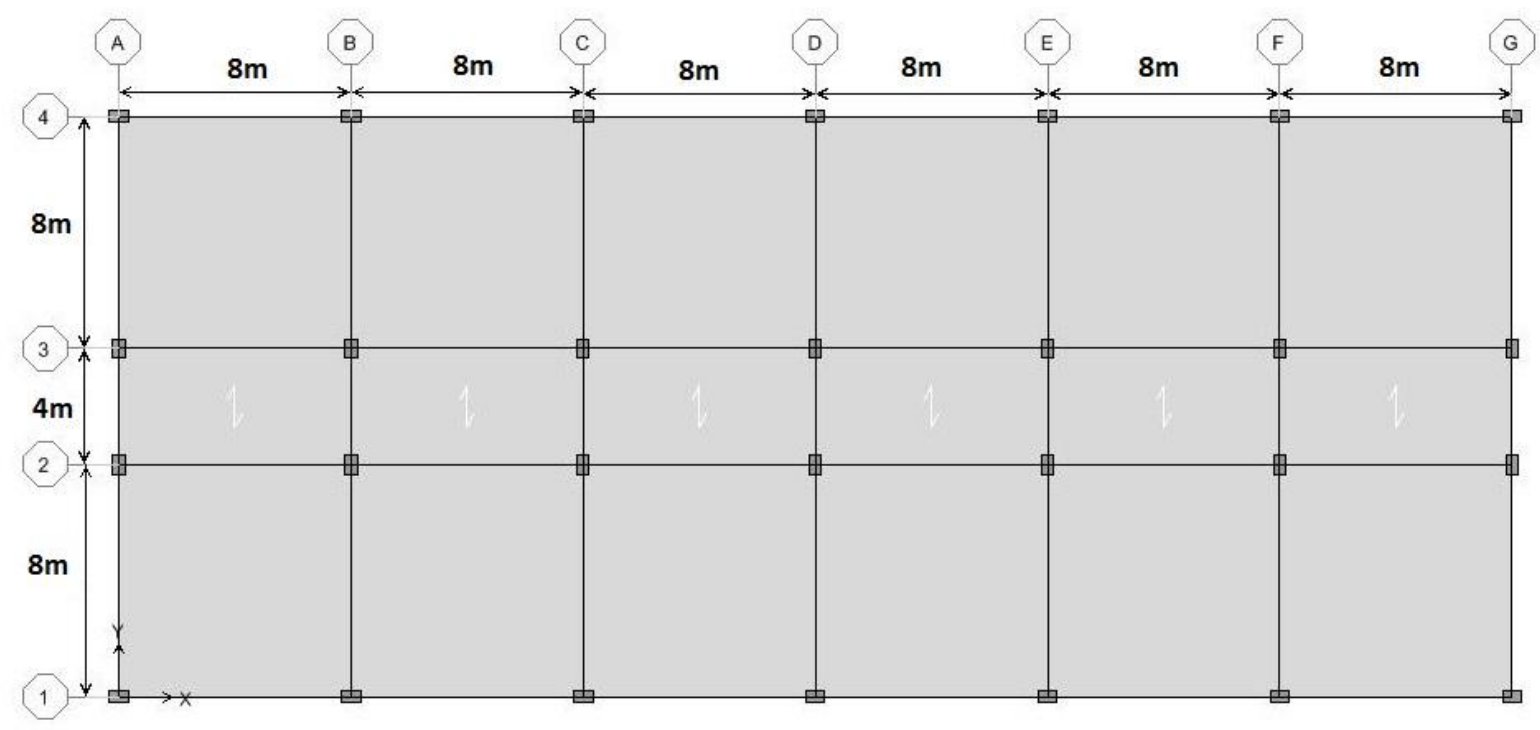

Fig 2.2 a: Building plan

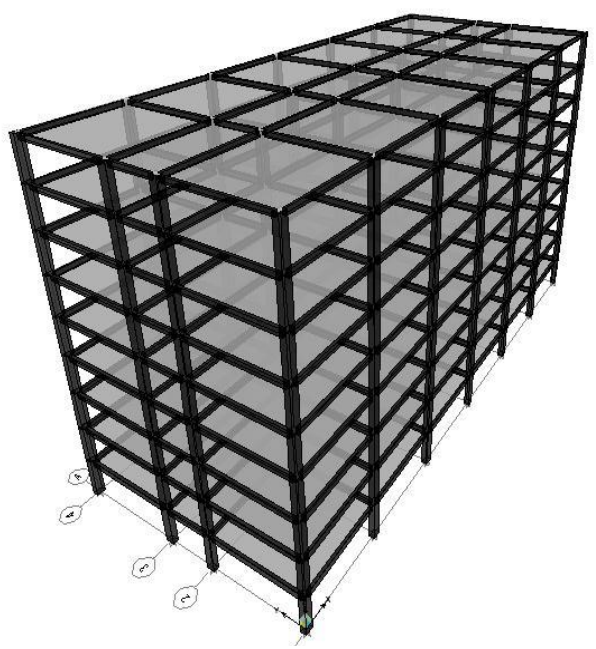

Fig 2.2.b: 3D view

In this thesis, there are two types of models, namely Basic model and combined model

Basic model(BM) is a model in which, for chosen value of $\mathrm{R}$ different optimized sizes of beams are obtained over the height. The beam sizes decreases over the height. The Basic models are type 1 ,type 2 and type 3 .

- optimized frame for $\mathrm{R}=3$ is Type 1 model.

- optimized frame for $\mathrm{R}=4$ is Type 2 model.

- optimized frame for $\mathrm{R}=5$ is Type 3 model..

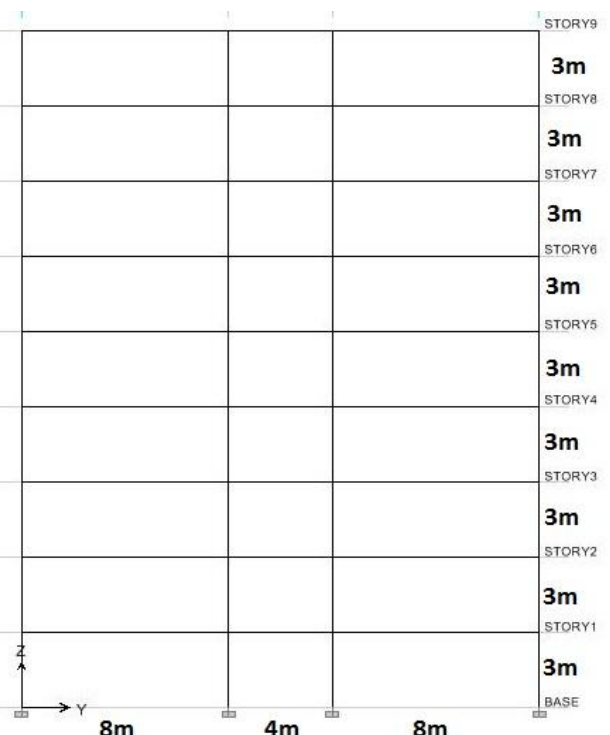

Fig 2.2.c: Building Elevation

Combined model (CM) is a model in which, the optimized beam sizes obtained from various $\mathrm{R}$ values are combined in a single model. The lower one third is taken from TYPE1, the middle third from TYPE2 and upper third from TYPE3 . Combined models is also analysed by response spectrum for $\mathrm{R}=3,4$ and 5 respectively and the results are identified as Type $4.1,4.2$ and 4.3 respectively.

The combined model is designed for different base shear obtained from $\mathrm{R}=3,4$ and 5 respectively. 


\section{TYPES OF MODELS}

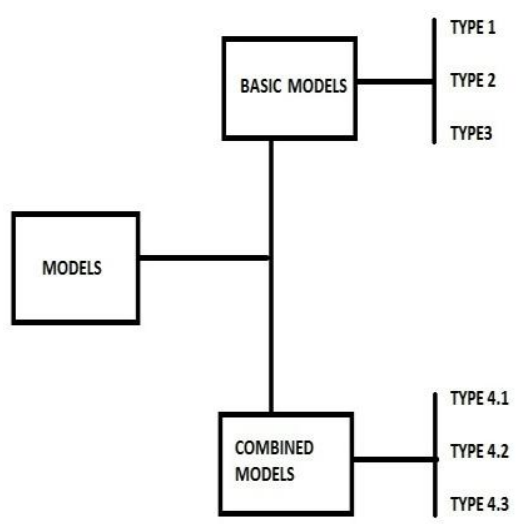

The steps for creating the types of optimum models

Two types of combined models have been employed in the present study. In one type, the optimized beam of the basic models are combined and that is called Type4. In the other type called Type8,the columns which are optimized in the basic models Type1,2\&3 are combined.

\subsection{Type4-Combination of Optimized Beams}

STEP1- A 9-Storey building is designed for different value of $\mathrm{R}$, They are $\mathrm{R}=3,4 \& 5$ and analysed by response spectrum method .In the analysis the dimension of the beams have been reduced gradually till they fail. The dimensions of the beams one step before they failed have been assumed to be the optimum dimension. The column dimensions have been kept constant. The frames for $\mathrm{R}=3,4$ \& 5 have been named TYPE -1,TYPE-2 AND TYPE3.

STEP2-A combined model where the dimensions of $1 / 3^{\text {rd }}$ bottom storey are given the dimensions of TYPE1, the next three stories are given the dimensions of TYPE2 and the last three (upper) stories are given the dimension of TYPE 3.

STEP3- The combined model is named as TYPE 4

STEP4-The type 4 is again analyzed for $R=3,4$ \& 5 respectively by the Response spectrum method. They are named as TYPE 4.1,TYPE 4.2 AND TYPE 4.3 respectively.

\subsection{Type8-Combination of Optimized Columns}

STEP1- A 9-Storey building is designed for different value of $\mathrm{R}$, They are $\mathrm{R}=3,4 \& 5$ and analysed by response spectrum method .In the analysis the dimension of the beams have been reduced gradually till they fail. The dimensions of the columns one step before they failed have been assumed to be the optimum dimension. The column dimension have been kept constant. The frames for $\mathrm{R}=3,4 \& 5$ have been named TYPE 5,TYPE-6AND TYPE7.

STEP2-A combined model where the dimensions of $1 / 3^{\text {rd }}$ bottom storey are given the dimensions of TYPE5, the next three stories are given the dimension of TYPE6 and last three (upper) stories are given the dimension of TYPE 7 is termed.

STEP3- The combined model is named as TYPE 8

STEP4-The type 8 is again analyzed for $\mathrm{R}=3,4$ \& 5 respectively by the Response spectrum method. They are named as TYPE 8.1,TYPE 8.2 AND TYPE 8.3 respectively.

\section{RESPONSE SPECTRUM ANALYSIS}

\subsection{Analysis Input}

Table below shows input for response spectra analysis for various types of models

Table 3.1.1 Response spectrum data

\begin{tabular}{|l|l|l|l|l|l|l|}
\hline & \multicolumn{3}{|c|}{ BASIC MODELS } & \multicolumn{2}{c|}{ COMBINED MODELS } \\
\hline TYPES & \multicolumn{1}{|c|}{$\mathrm{T} 1$} & $\mathrm{~T} 2$ & $\mathrm{~T} 3$ & $\mathrm{~T} 4.1$ & $\mathrm{~T} 4.2$ & $\mathrm{~T} 4.3$ \\
\hline R VALUE & $\mathrm{R}=3$ & $\mathrm{R}=4$ & $\mathrm{R}=5$ & $\mathrm{R}=3$ & $\mathrm{R}=4$ & $\mathrm{R}=5$ \\
\hline Function input & 0.1 & 0.1 & 0.1 & 0.1 & 0.1 & 0.1 \\
\hline spectrum case name & $\mathrm{spec} 1$ & $\mathrm{spec} 1$ & spec1 & spec1 & spec1 & spec1 \\
\hline structural and function damping & 0.05 & 0.05 & 0.05 & 0.05 & 0.05 & 0.05 \\
\hline model combination & $\mathrm{CQC}$ & $\mathrm{CQC}$ & $\mathrm{CQC}$ & $\mathrm{CQC}$ & $\mathrm{CQC}$ & $\mathrm{CQC}$ \\
\hline directional combination & $\mathrm{SRSS}$ & $\mathrm{SRSS}$ & $\mathrm{SRSS}$ & $\mathrm{SRSS}$ & $\mathrm{SRSS}$ & $\mathrm{SRSS}$ \\
\hline input response spectra & $9.81 / 2 * 3$ & $9.81 / 2 * 4$ & $9.81 / 2 * 5$ & $9.81 / 2 * 3$ & $9.81 / 2 * 4$ & $9.81 / 2 * 5$ \\
\hline eccentricity ratio & 0.05 & 0.05 & 0.05 & 0.05 & 0.05 & 0.05 \\
\hline
\end{tabular}




\subsection{Results}

\subsubsection{Comparison of Basic Model with Combined Model -Type4}
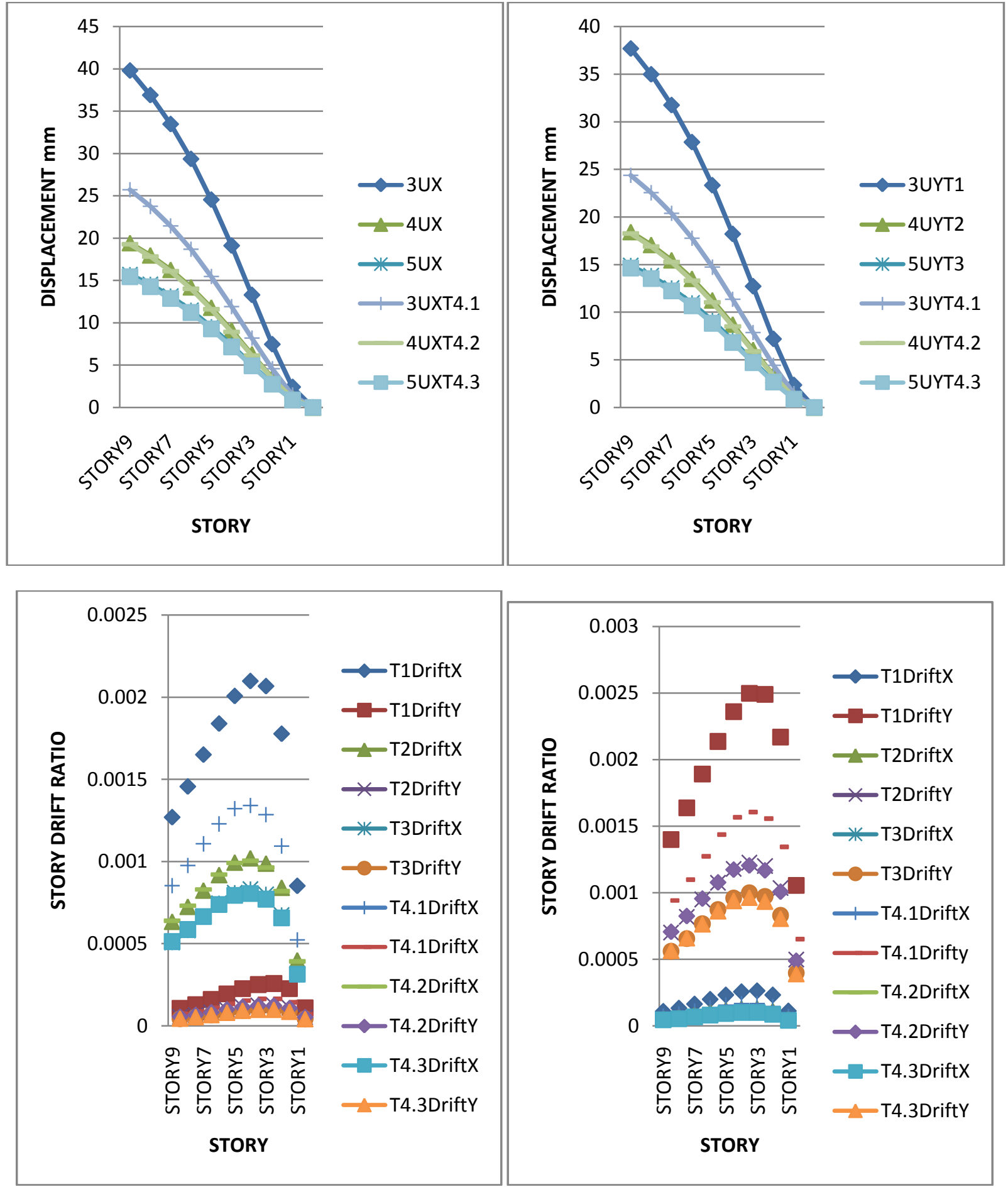

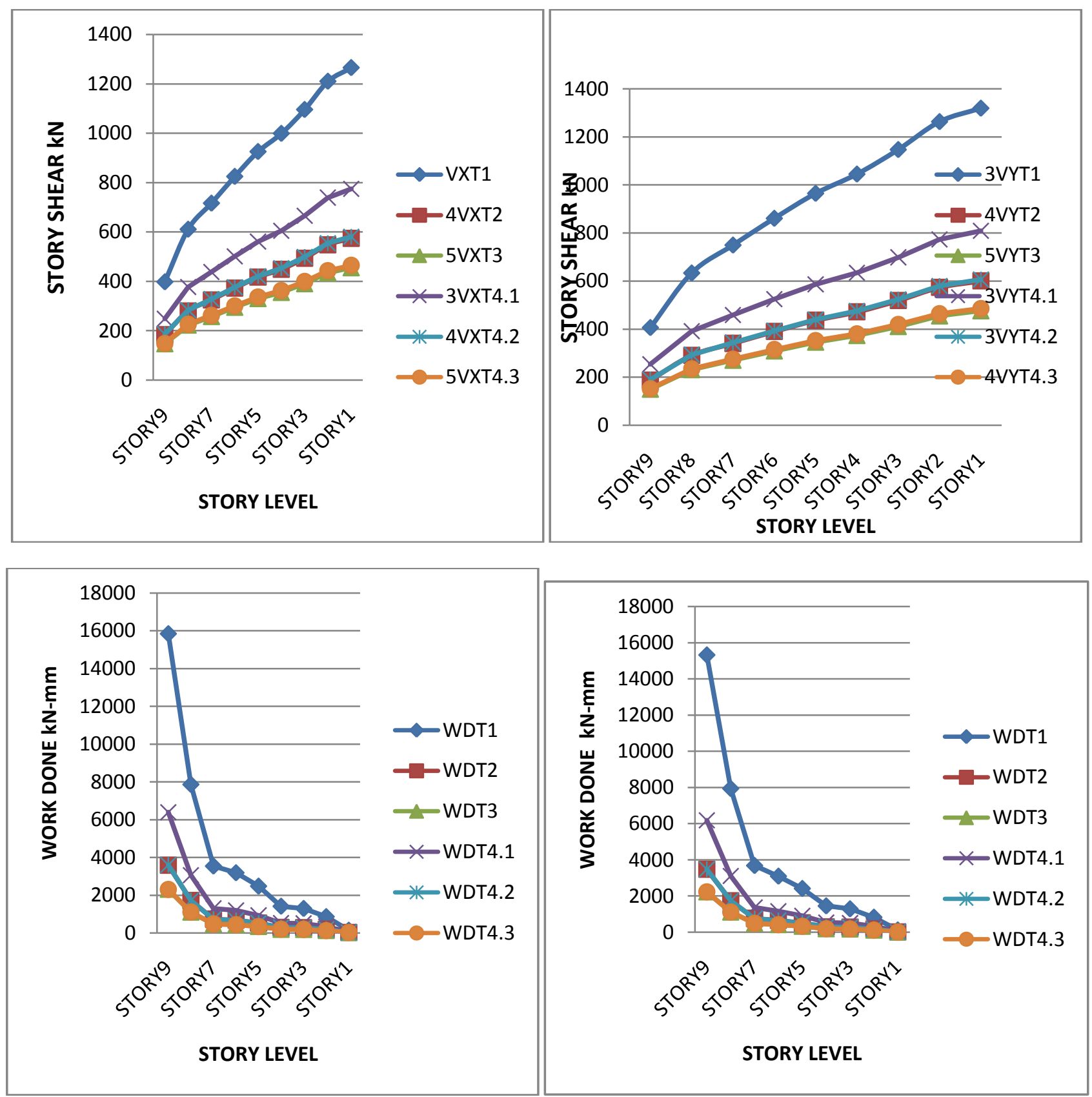

Chart 1- EARTQUAKE IN X-DIRECTION

Chart 2- EARTQUAKE IN Y-DIRECTION

\subsubsection{Base Shear, Displacement and Work done}

Table 3.2.1 Base shear, displacement and work done

\begin{tabular}{|l|l|l|l|l|}
\hline $\begin{array}{l}\text { KIND OF RESPONSE OF } \\
\text { STRUCTURE IN X DIRECTION }\end{array}$ & R VALUUE & BASIC MODEL & $\begin{array}{l}\text { COMBINED } \\
\text { MODEL }\end{array}$ & REDUCTION(\%) \\
\hline & 3 & 39.7957 & 25.6995 & 35.42141488 \\
\hline DISPLACEMENT(MM) & 4 & 19.4271 & 19.2747 & 0.784471177 \\
\hline & 5 & 15.6773 & 15.4197 & 1.643140082 \\
\hline
\end{tabular}




\begin{tabular}{|l|l|l|l|l|}
\hline & 3 & 15836.3 & 6384.013 & 59.6874711 \\
\hline Work Done KN/mm2 & 4 & 3582.163 & 3591.069 & -0.00248 \\
\hline & 5 & 2306.915 & 2298.152 & -0.00379 \\
\hline $\begin{array}{l}\text { KIND OF RESPONSE OF } \\
\text { STRUCTURE IN Y-DIRECTION }\end{array}$ & R VALUUE & BASIC MODEL & $\begin{array}{l}\text { COMBINED } \\
\text { MODEL }\end{array}$ & $\begin{array}{l}\text { AVEARGE } \\
\text { REDUCTION }\end{array}$ \\
\hline & 3 & 37.6768 & 24.3573 & 35.3519938 \\
\hline DISPLACEMENT(MM) & 4 & 18.4339 & 18.268 & 0.008 \\
\hline & 5 & 14.8885 & 14.6144 & 0.018 \\
\hline Work Done KN/mm2 & 3 & 15315.24 & 6186.511 & 59.6055236 \\
\hline & 4 & 3474.421 & 3479.871 & -0.001566 \\
\hline
\end{tabular}

\subsubsection{Base Shear}

\section{X-Direction}

\begin{tabular}{|l|l|l|l|l|}
\hline NO & R VALUE & Vs(KN)BASICMODEL & $\begin{array}{l}\text { Vs(KN)COMBINED } \\
\text { MODEL }\end{array}$ & REDUCTION(\%) \\
\hline 1 & 3 & 1264.84 & 774.34 & 38.77973113 \\
\hline 2 & 4 & 574.04 & 580.76 & -1.16855154 \\
\hline 3 & 5 & 455.15 & 464.61 & -2.077565979 \\
\hline
\end{tabular}

\section{Y-Direction}

\begin{tabular}{|l|l|l|l|l|}
\hline NO & R VALUE & $\begin{array}{l}\text { Vs(KN) } \\
\text { BASICMODEL }\end{array}$ & $\begin{array}{l}\text { Vs(KN)COMBINED } \\
\text { MODEL }\end{array}$ & REDUCTION(\%) \\
\hline 1 & 3 & 1319.41 & 809.32 & 38.66 \\
\hline 2 & 4 & 600.34 & 606.99 & -1.09 \\
\hline 3 & 5 & 476.31 & 485.59 & -1.91 \\
\hline
\end{tabular}

\subsubsection{Type 8}
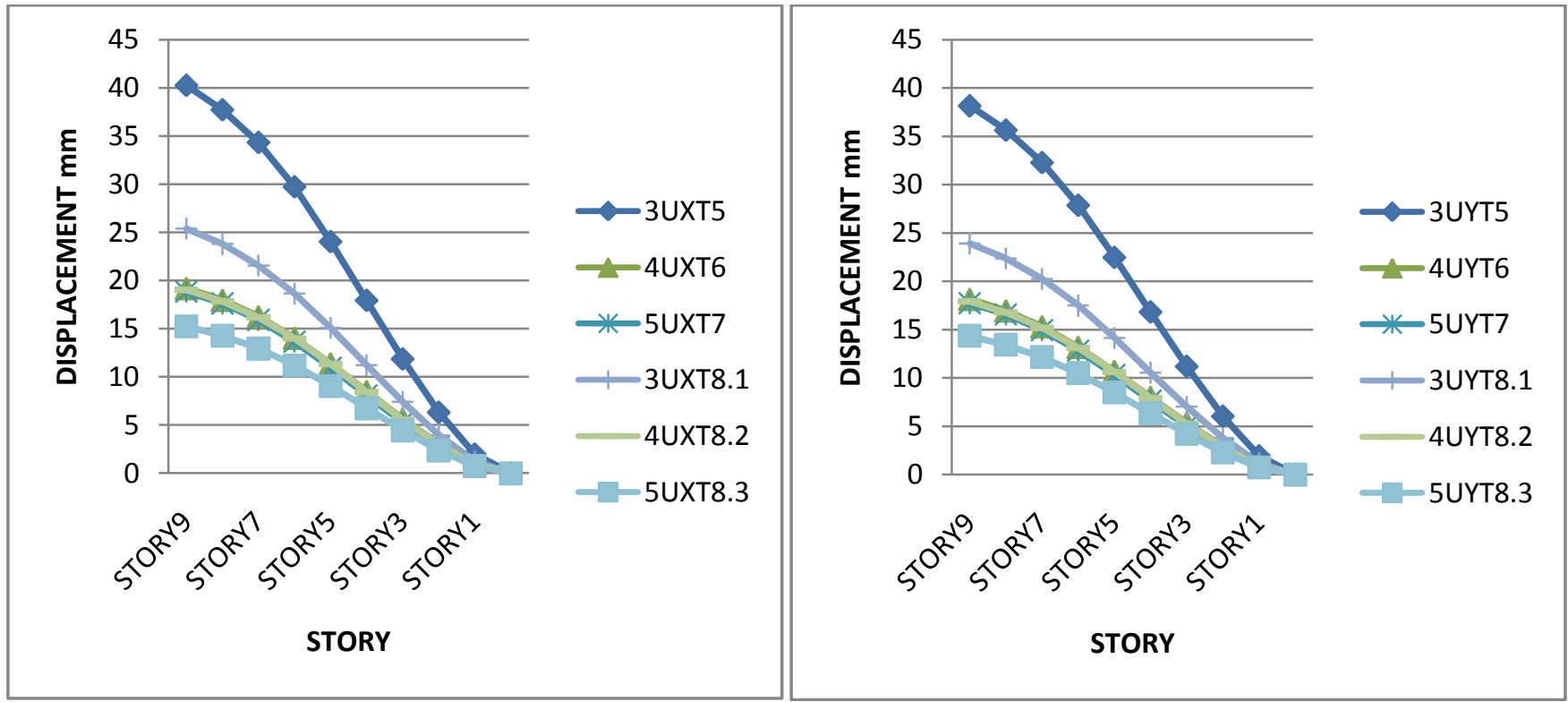

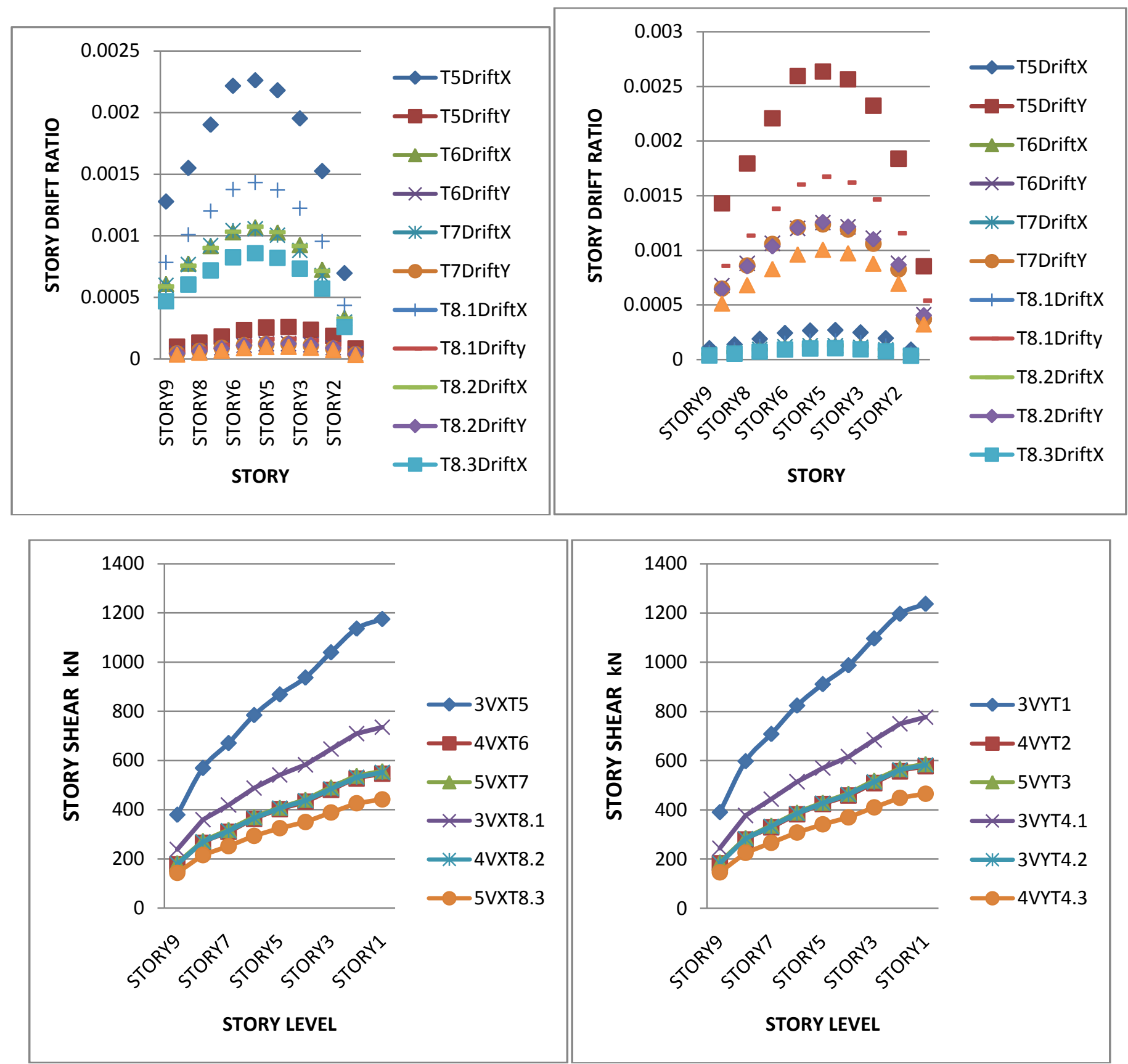


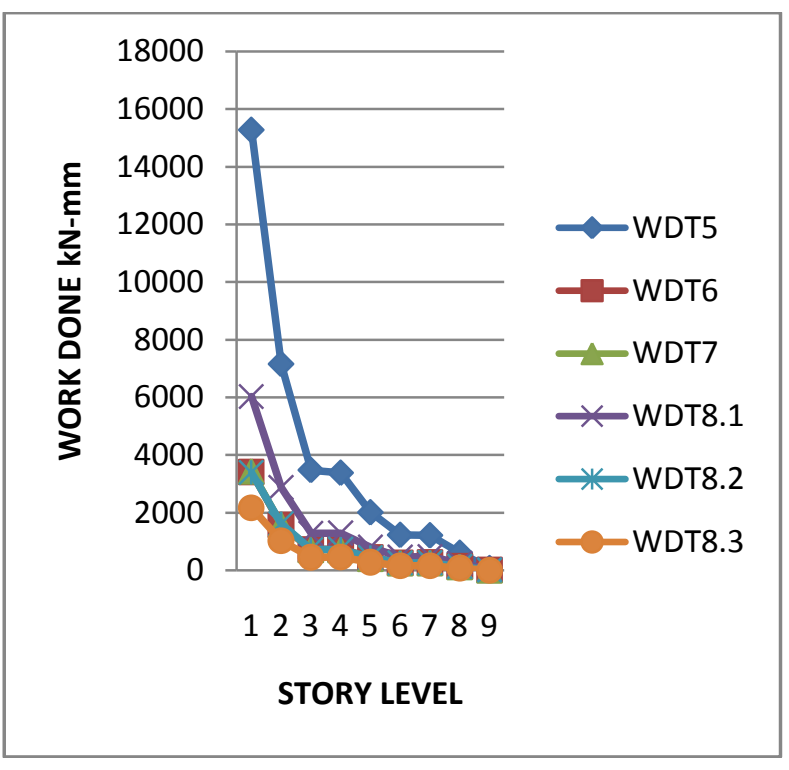

Chart 1.1- EARTQUAKE IN X-DIRECTION

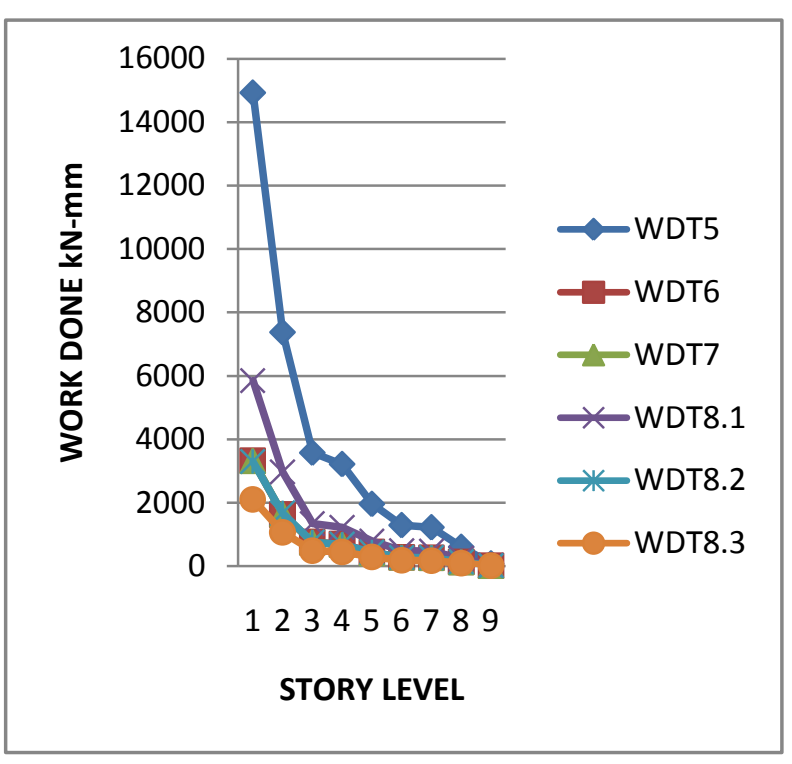

Chart 2.1 - EARTQUAKE IN Y-DIRECTION

\subsubsection{Base Shear, Displacement and Workdone}

Table 3.2.3 Base shear, displacement and workdone

\begin{tabular}{|l|l|l|l|l|}
\hline $\begin{array}{l}\text { KIND OF RESPONSE OF } \\
\text { STRUCTURE IN X DIRECTION }\end{array}$ & R VALUUE & BASIC MODEL & $\begin{array}{l}\text { COMBINED } \\
\text { MODEL }\end{array}$ & $\begin{array}{l}\text { AVEARGE } \\
\text { REDUCTION }\end{array}$ \\
\hline & 3 & 40.252 & 25.3722 & 36.966 \\
\hline DISPLACEMENT(MM) & 4 & 19.1996 & 19.0292 & 0.008875 \\
\hline & 5 & 18.8359 & 15.2233 & 19.1733 \\
\hline Rork Done KN/mm2 & 3 & 15269.6 & 6030.464 & 60.50 \\
\hline \multicolumn{1}{|l|}{ RINDPONSE OF } & R VALUUE & BASIC MODEL & $\begin{array}{l}\text { COMBINED } \\
\text { MODEL }\end{array}$ & $\begin{array}{l}\text { AVEARGE } \\
\text { REDUCTION }\end{array}$ \\
\hline & 4 & 3411.193 & 3392.145 & 0.00558 \\
\hline DISPLACEMENT(MM) & 5 & 3436.987 & & 36.83 \\
\hline & 3 & 38.1533 & 23.9095 & 37.3333 \\
\hline & 4 & 18.134 & 17.9321 & 0.0111 \\
\hline Work Done KN/mm2 & 5 & 17.7251 & 14.3457 & 19.065 \\
\hline & 3 & 14920.61 & 5853.046 & 60.77202 \\
\hline
\end{tabular}




\subsubsection{Base Shear}

\section{X-Direction}

\begin{tabular}{|l|l|l|l|l|}
\hline NO & R VALUE & $\begin{array}{l}\text { Vs(KN) } \\
\text { BASICMODEL }\end{array}$ & $\begin{array}{l}\text { Vs(KN)COMBINED } \\
\text { MODEL }\end{array}$ & REDUCTION(\%) \\
\hline 1 & 3 & 1174.46 & 735.37 & 37.3865 \\
\hline 2 & 4 & 546.3 & 551.53 & -0.00948 \\
\hline 3 & 5 & 556.84 & 441.22 & 20.763 \\
\hline
\end{tabular}

\section{Y-Direction}

\begin{tabular}{|l|l|l|l|l|}
\hline NO & R VALUE & Vs(KN) BASICMODEL & $\begin{array}{l}\text { Vs(KN)COMBINED } \\
\text { MODEL }\end{array}$ & REDUCTION(\%) \\
\hline 1 & 3 & 1236.67 & 776.62 & 37.200 \\
\hline 2 & 4 & 577.09 & 582.46 & -0.00921 \\
\hline 3 & 5 & 586.54 & 465.97 & 20.5561 \\
\hline
\end{tabular}

\section{PUSH OVER ANALYSIS}

\subsection{Types of Models}

The models which are used in response spectrum analysis are also used in pushover analysis. The sizes of columns and beams are same as of that models.(3.2.2-3a)

In case of beams optimization, the basic models are named as - optimized frame for $\mathrm{R}=3$ is Type 1 model.

- optimized frame for $\mathrm{R}=4$ is Type 2 model.

- optimized frame for $\mathrm{R}=5$ is Type 3 model.

And combined model is named as

-combined optimized frame for $\mathrm{R}=3$ is Type 4 model.

In case of column optimization, the basic models named as

- optimized frame for $\mathrm{R}=3$ is Type 5 model.

- optimized frame for $R=4$ is Type 6 model.

- optimized frame for $\mathrm{R}=5$ is Type 7 model.

And combined model is named as

-combined optimized frame for $\mathrm{R}=3$ is Type 8 model.

The steps for creating the types of optimum models are same as explained in 3 .
The loads considered are

Dead Load, Live Load, Floor Finish, and Earth Quake Load All models consist of these loads. They are explained in detail in chapter 3(3.2.3).Along with this pushover is also considered.

Pushover Analysis Data

\section{Hinge assignment}

For beam default M3 hinges and for column default P-M-M hinges are assign the default hinge properties available with the software. Default hinge properties are as per ATC-40 and FEMA 273.

Beams > default M3 $=0$ default $\mathrm{M} 3=1$

Columns $>$ default P-M-M $=0$ default P-M-M =1

Static non linear data for PUSH1

$\mathrm{DL}=$ Dead load factor 1

$\mathrm{LL}=$ Live load factor 0.5

$\mathrm{FF}=$ Floor finish factor 1

Static non linear data for PUSH2

$\mathrm{EQX}=-1$

\section{STATIC LOAD ASSIGNMENT}

\section{RESULTS}

COMPARISION OF BASIC MODEL WITH COMBINED MODEL

\section{-TYPE-4}

\section{CAPACITY SPECTRUM}




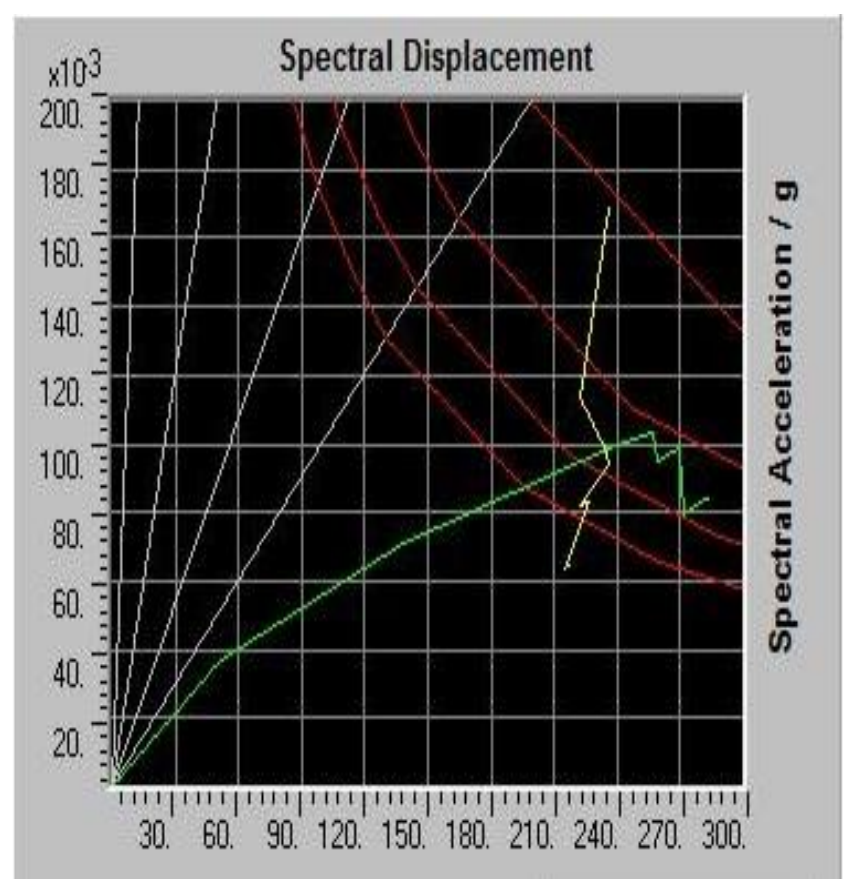

TYPE-1 MODEL

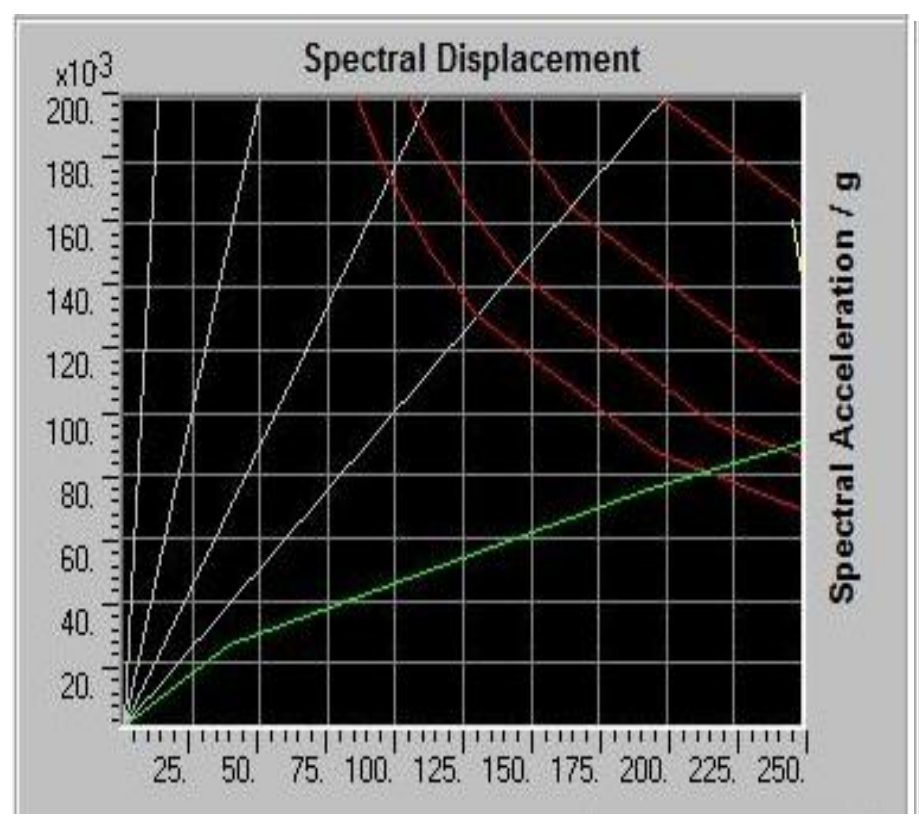

TYPE-3 MODEL

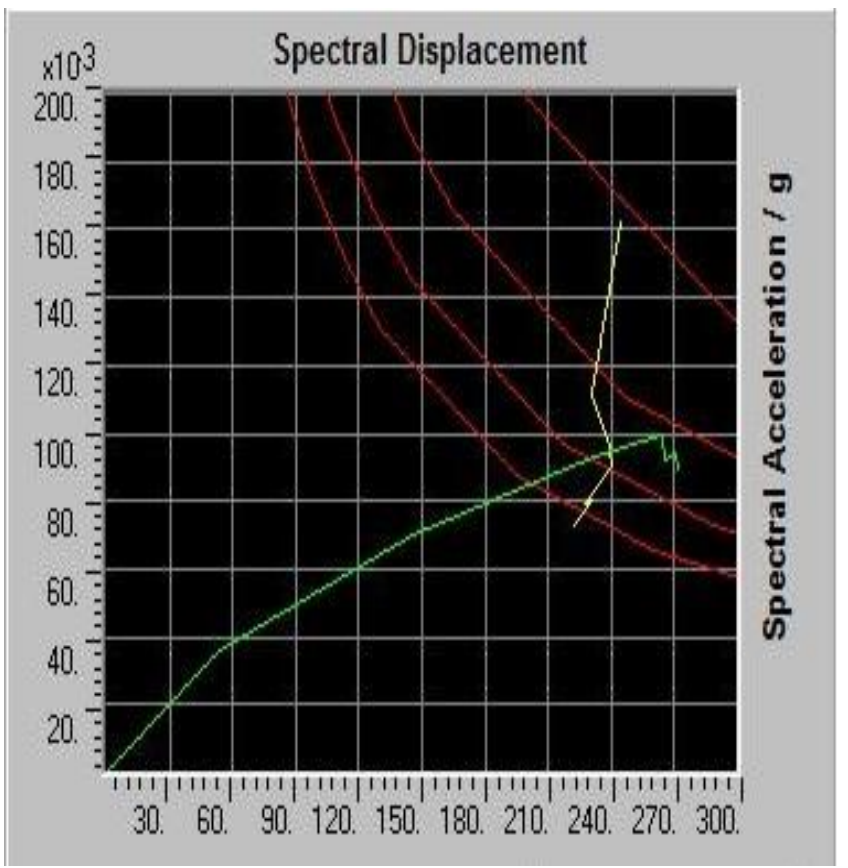

TYPE-2 MODEL

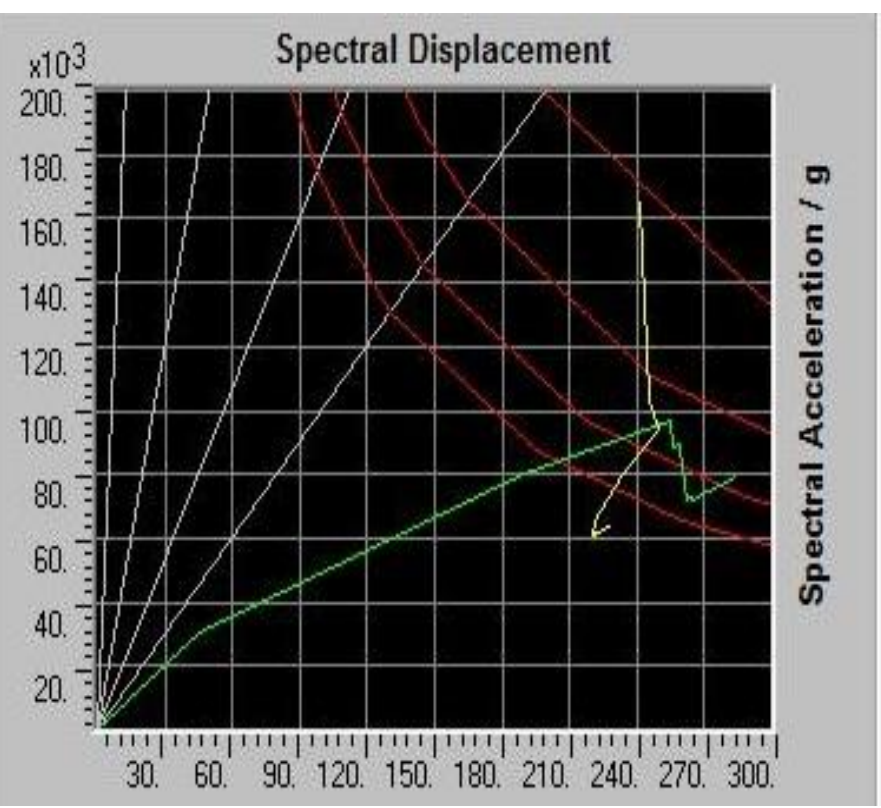

TYPE-4 MODEL

Displacements, Story drift ratio, Story shear \& Work done 


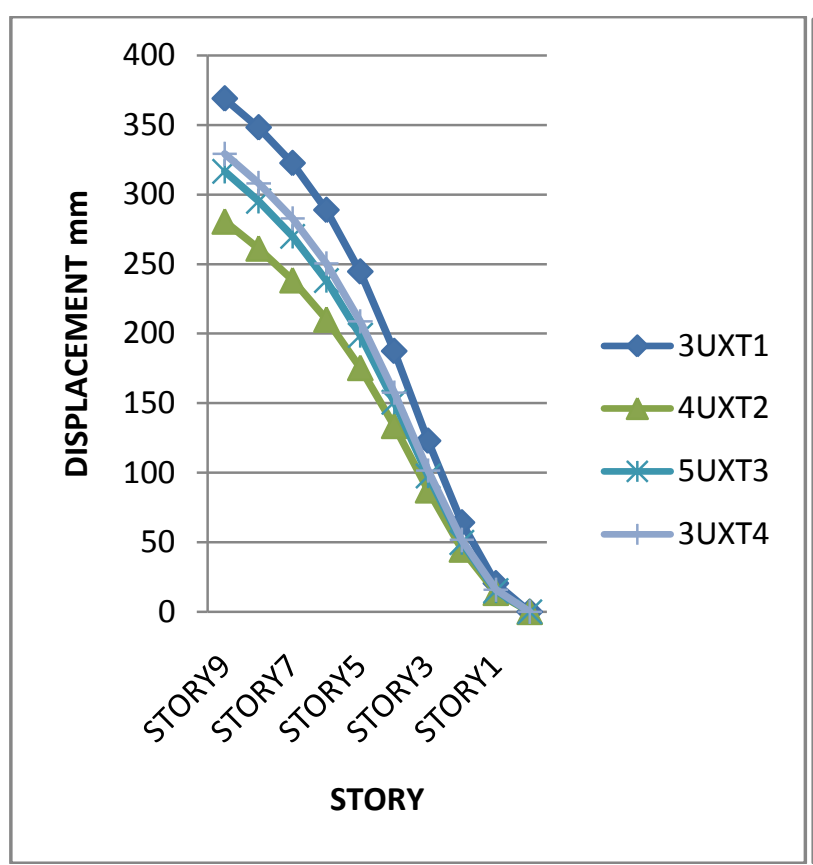

\section{Chart 4.1}

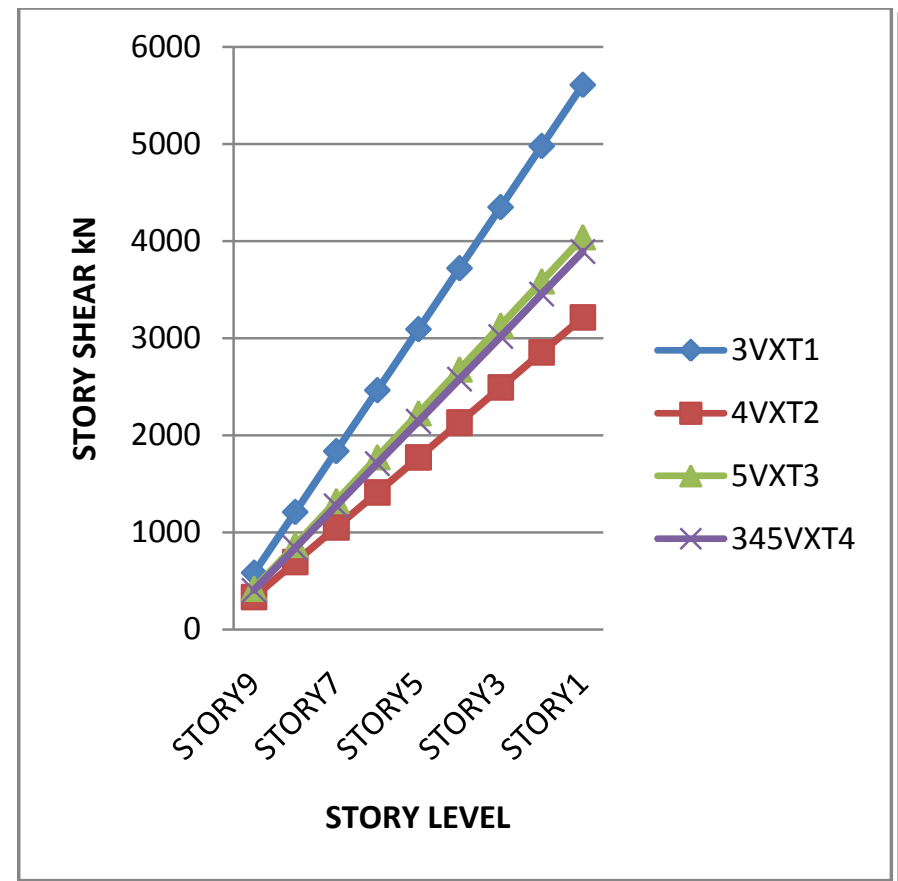

Chart 4.3

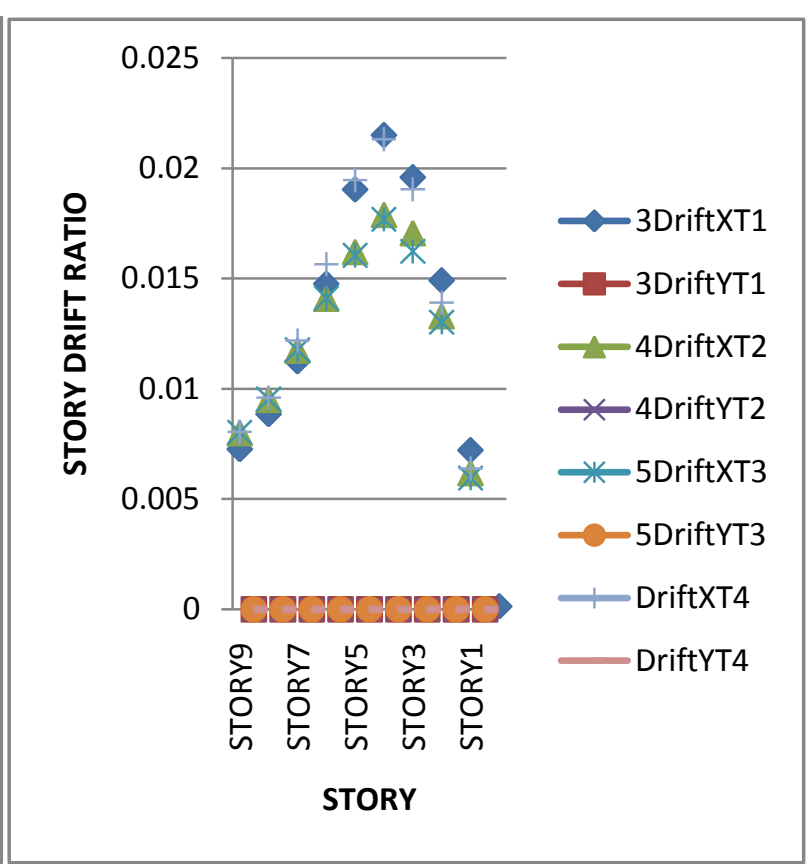

Chart 4.2

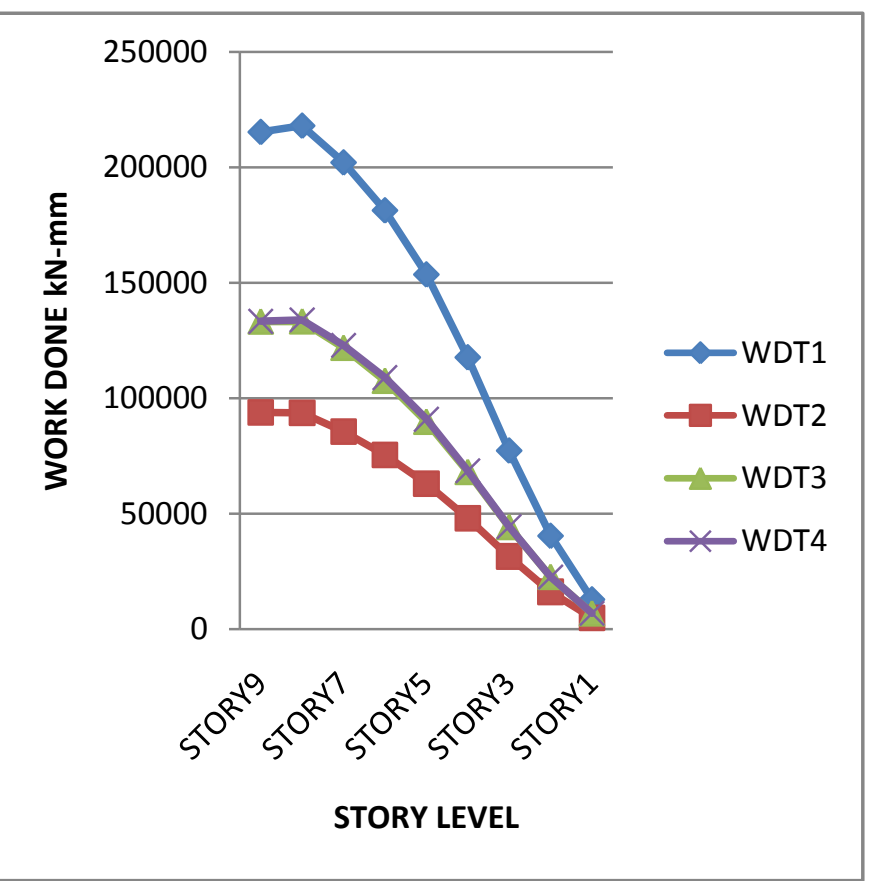

Chart 4.4

\section{-TYPE8}

\section{CAPACITY SPECTRUM}




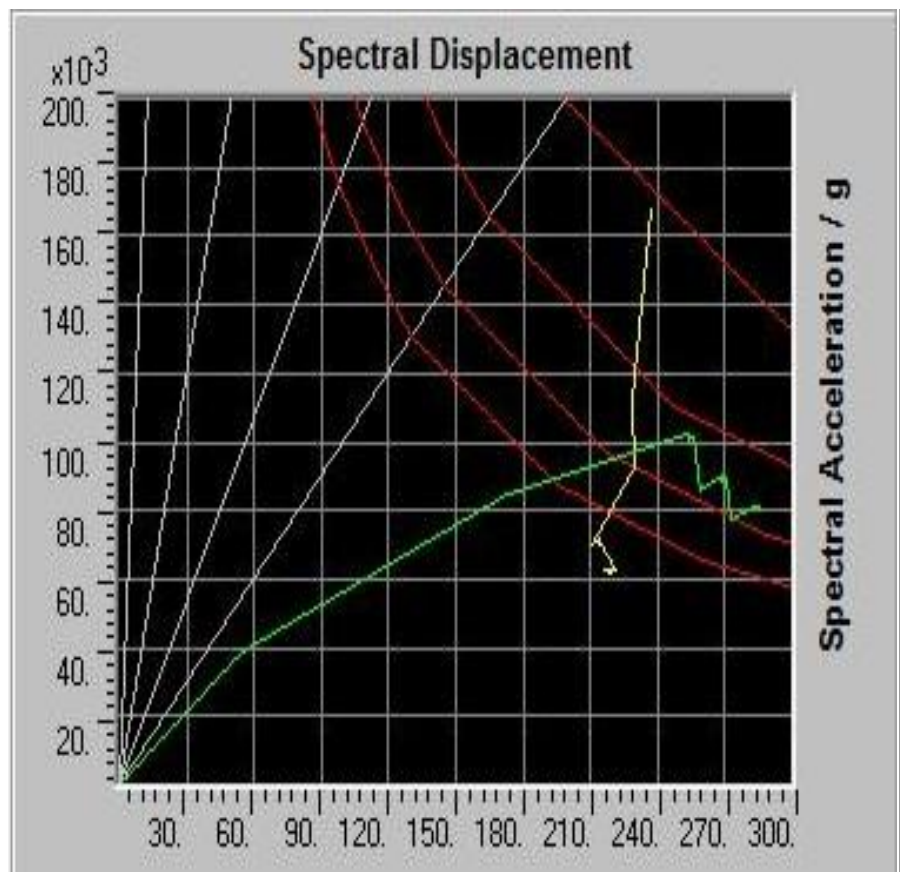

TYPE-1 MODEL

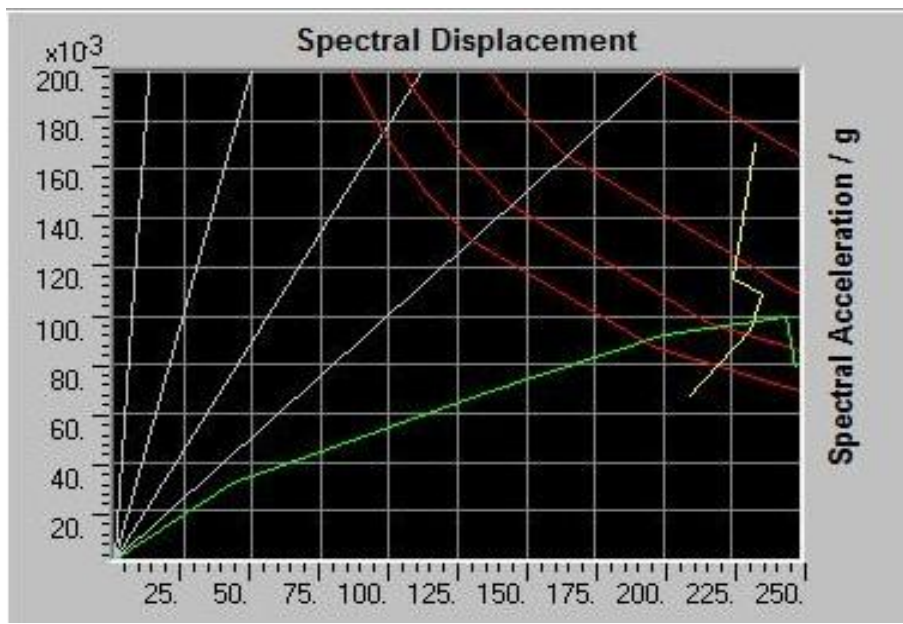

TYPE-3 MODEL

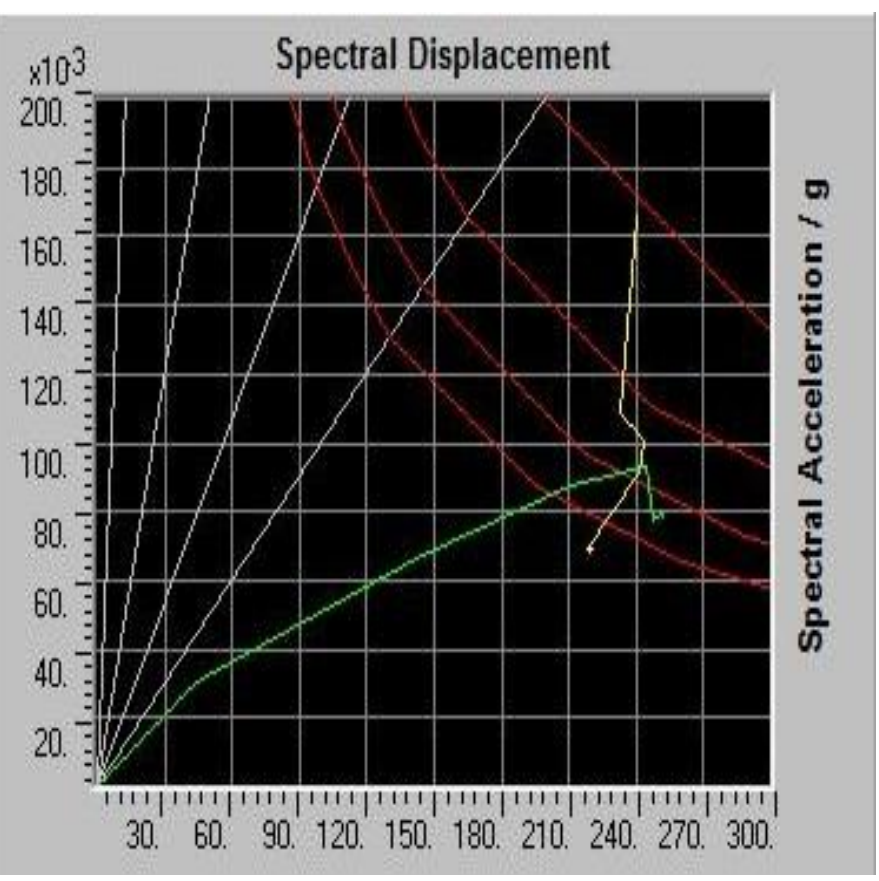

TYPE-2 MODEL

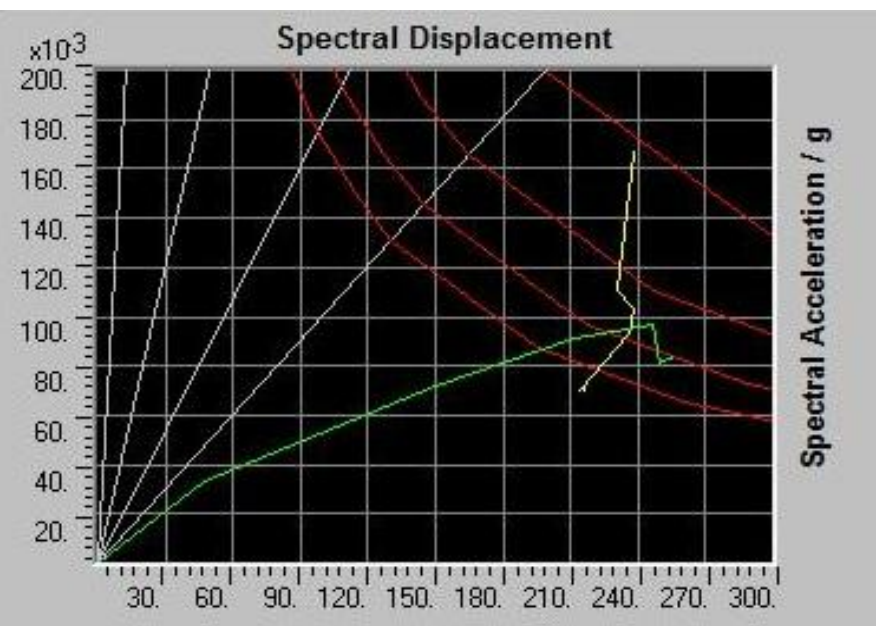

TYPE-4 MODEL

\section{Displacements, Story drift ratio, Story shear \& Work done}



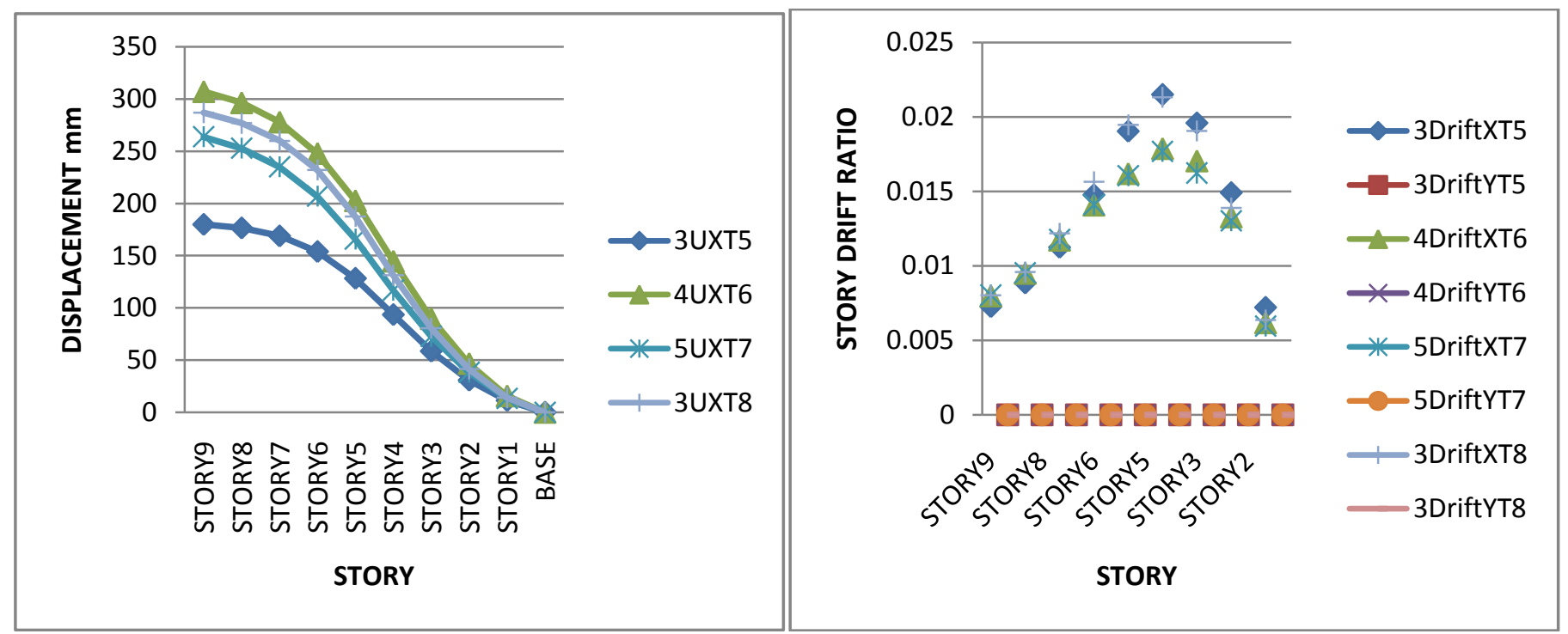

\section{Chart 4.5}

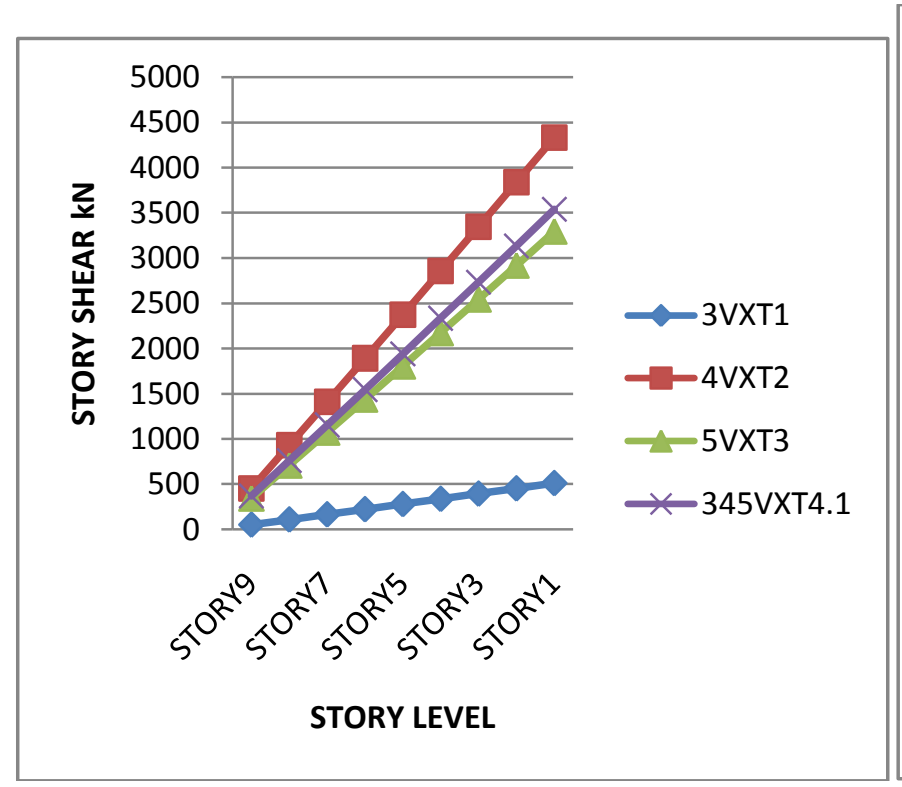

Chart 4.7

\section{EXPENDABLE TOP STOREY (ETS)}

As we know that, most of the structures undergo yielding during strong ground motions. This means that structures undergo nonlinear deformations during earthquakes. In this paper, the possibilities of absorber behavior have been explored for yielding structures subjected to earthquake ground motions. A nine-storeyed, structure has been chosen for the purposes of this study. The objective of the investigation is to find the circumstances under which the storey of the structure could absorb a major portion of the energy input, thus reducing the response levels of the lower
Chart 4.6

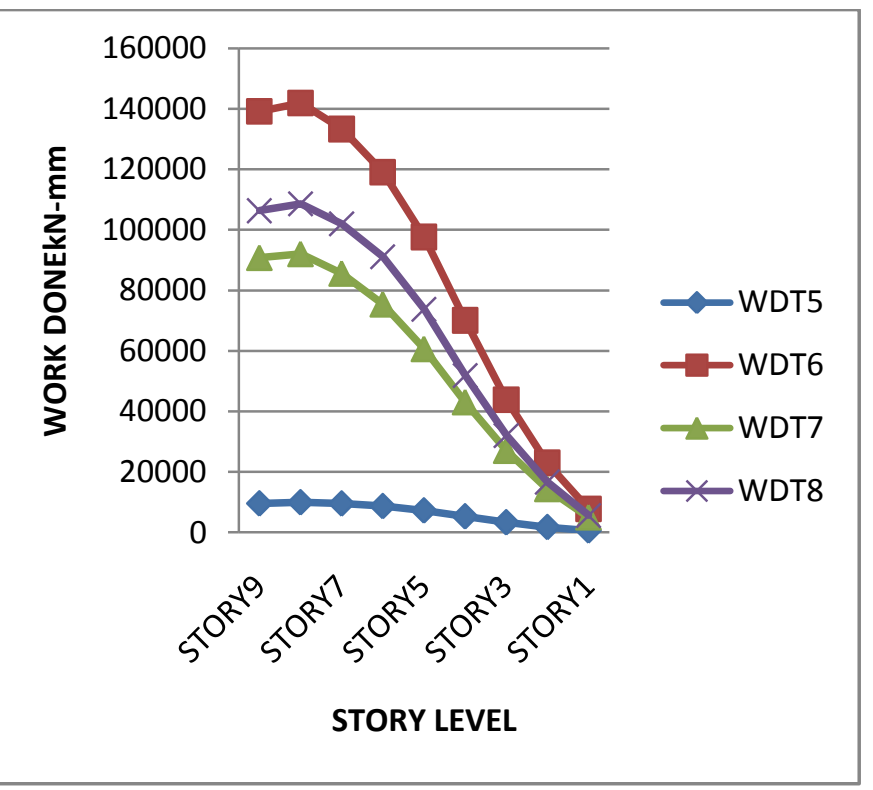

Chart 4.8 
structure. The top storey would then behave like a mechanical fuse undergoing large deformations. However, the problem of designing the top storey to withstand the large ductility demand placed on it needs to be looked into. The fact that the absorber system has a lower mass compared to that of the main structure probably favours the practical design of the top storey. The concept was first proposed in an earlier research (Jagadish and Raghu Prasad).
In general, the top mass experiences much larger ductilities than the lower mass. It is also seen that as the strength of the upper storey is reduced, its maximum displacement increases in proportion. That is completely in contrast with the response characteristics of the lower stories.

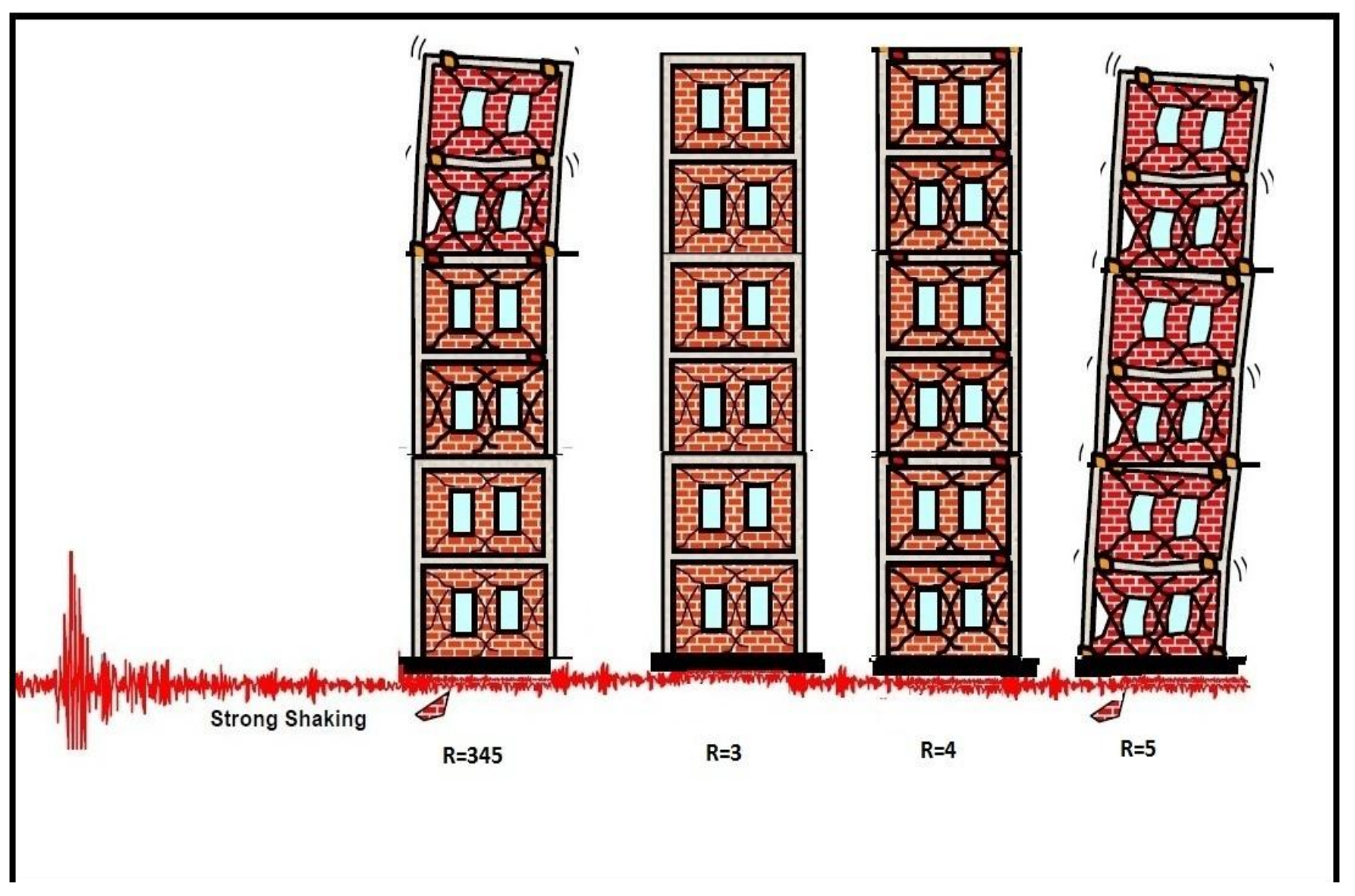

Fig 5.1 Expendable top storey

\section{STRUCTURAL MODEL}

For this study, building with nine storey is considered. The dimension in plan of the building are $48 \mathrm{mX} 20 \mathrm{~m}$. The structural models have the same story height of $3 \mathrm{~m}$. and have a uniform mass distribution over their height.Building plan is shown is $3.2 \mathrm{a}$

The 3D model shown in fig $3.2 \mathrm{~b}$ and fig $3.2 \mathrm{c}$ shows the building elevation. The same optimized sections obtained in Response Spectrum analysis are also used here. The steps for creating optimum models are the same as explained in 3.2.1.

The sizes for bottom 4 stories are obtained from type $1(\mathrm{R}=3)$ model, next 4 stories are obtained from type $2(\mathrm{R}=4)$ and top most storey is from the type $3(\mathrm{R}=5)$. Now this structure is subjected to response spectrum analysis and designed. The failing beams and columns are optimized. This model is used for push over analysis.

\section{STATIC LOAD ASSIGNMENT}

The loads considered are

Dead Load, Live Load, Floor Finish, and Earth Quake Load. All models consist of these loads. They are explained in detail in chapter 3(3.2.3).Along with this pushover is also considered.

Pushover Analysis Data

Hinge assignment

For beam default M3 hinges and for column default P-M-M hinges are assign the default hinge properties available with 
the software. Default hinge properties are as per ATC-40 and FEMA 273.

Beams > default M3 $=0$ default M3=1

Columns $>$ default P-M-M $=0$ default P-M-M =1

Static non linear data for PUSH1

\section{RESULTS}
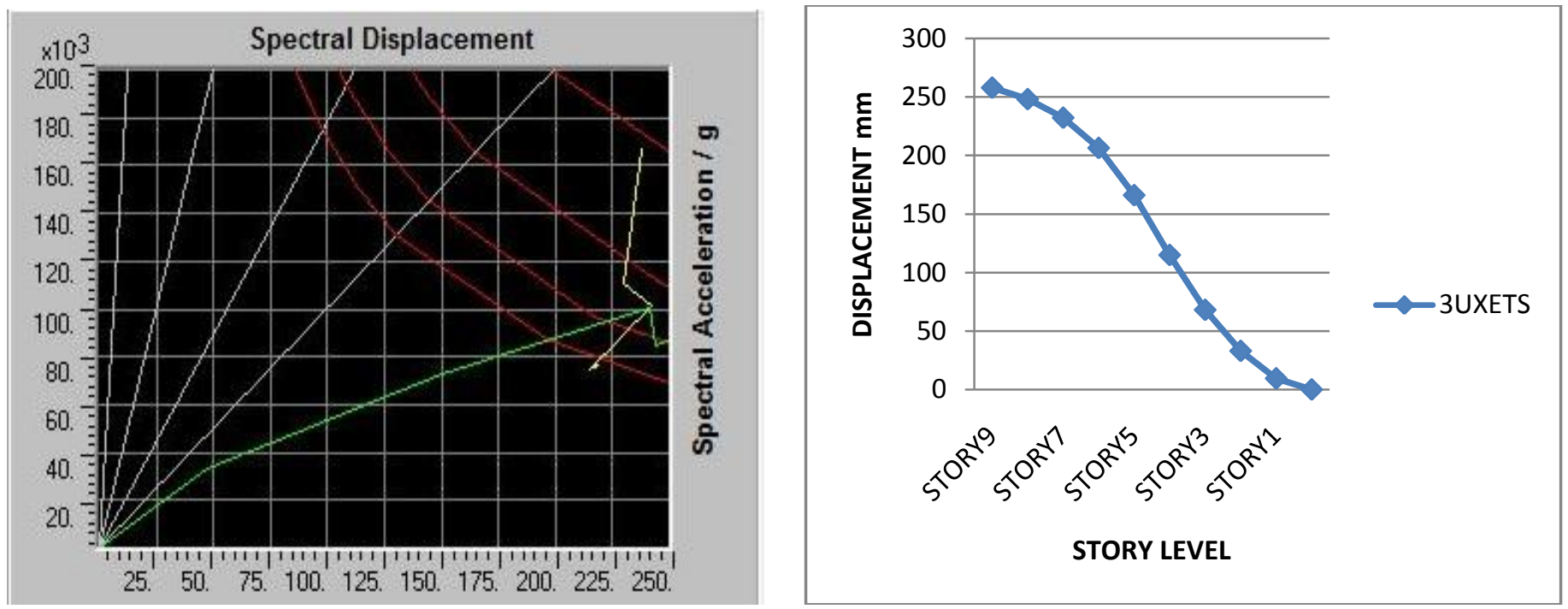

CHART 6.1

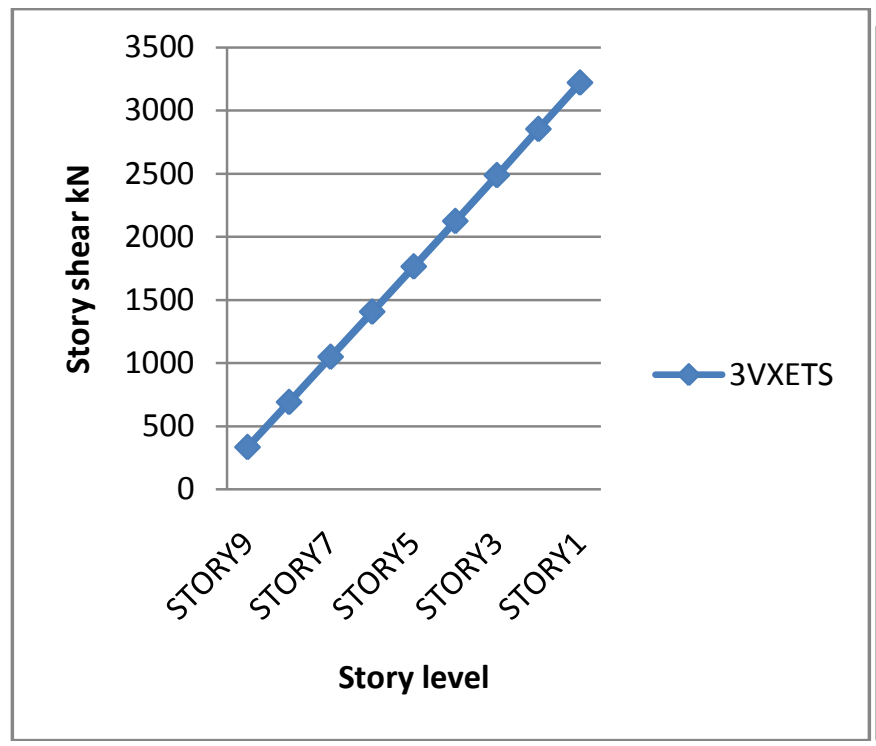

Chart 6.2

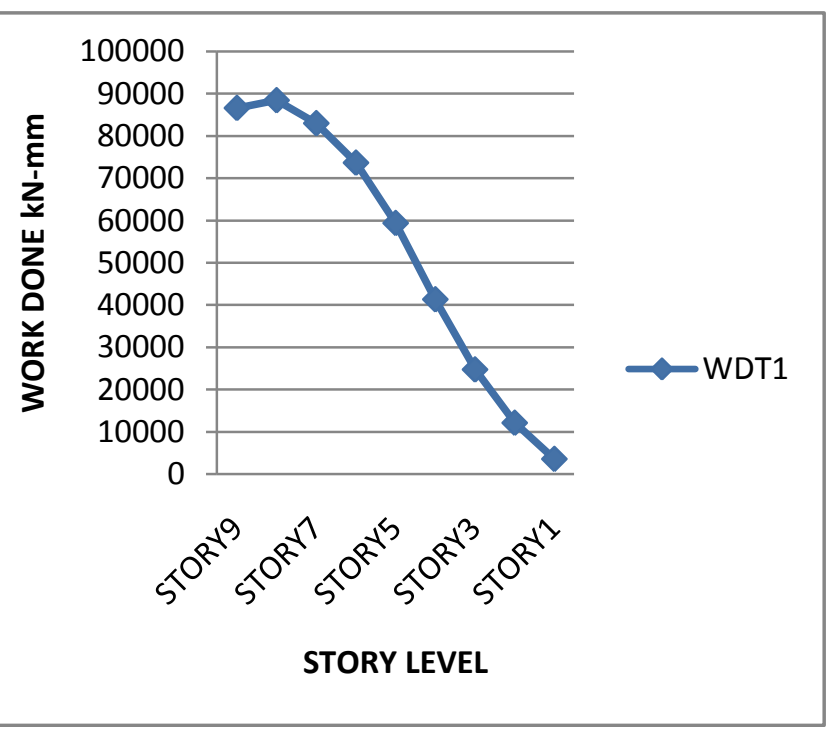

Chart 6.3
$\mathrm{DL}=$ Dead load factor 1

LL=Live load factor 0.5

$\mathrm{FF}=$ Floor finish factor 1

Static non linear data for PUSH2

$\mathrm{EQX}=-1$

\section{DISCUSSIONS}

\section{Capacity spectrum}

The capacity spectrum curve of the models are shown in Fig. Red curve in Fig shows the response spectrum curve for 


\section{Displacement (mm)}

As it can be seen from figures, the displacement of the stories of structures is reduced by developing a combined model. Furthermore the graph shows that there has been steady increase in the amount of displacement of stories over the height.

According to this concept, the reduction of displacement of stories is due to increase of stiffness of structure as well as decrease of velocity and acceleration of structure. In other words by creating the combined model, the response of structure such as velocity and acceleration can be reduced and it is the cause of reduction of displacement.

\section{Story Drift Ratio}

It is the displacement of one level relative to the other level above or below.

The building may collapse due to different response quantities. For eg., at local levels such as strains, curvatures, rotations and at global levels such as interior story drifts.

Individual stories may exhibit excessive lateral displacement. Therefore it can be concluded that by decreasing the story drifts of structure, the probability of collapse of the building can be reduced. To do that, as it is mentioned, combined model can play a significant rule to reduce response of structure

\section{Story Shear $(\mathbf{k N})$}

It is the sum of design lateral forces at all levels above the storey under consideration.

As it can be seen from figures, the maximum top story shear and minimum top story shear. Furthermore the graph shows that there has been steady decreasing in the amount of story shear over the height. In all models, the story shear at the base is more and at the top stories shear is less.

\section{Work Done (kN-mm)}

Work done is obtained as a product of lateral force of each storey and the corresponding displacement.

In the figures, the maximum workdone and minimum workdone is shown. The curves shown in figure, fallows the patterns of mode shape. It is seen that the workdone is maximum at the top 3 stories and has much higher value when compared to bottom stories. This is due to the higher $\mathrm{R}$ value at these stories. This implies that there is increased energy absorption at the top stories.

\section{RECOMMENDATION AND CONCLUSIONS}

\section{Overview}

The present study was designed to determine the optimum earthquake response of tall building by combining the different structural element sections obtained from different values of $\mathrm{R}$. The main objectives of the study are stated in the chapter one. The purpose of the study is to investigate whether the combined model provides adequate energy dissipation.

\section{Conclusions}

The following conclusions are drawn from the present study RESPONSE SPECTRUM ANALYSIS

The results show that the combined model with beams selected from the frames designed for $\mathrm{R}=3,4$ \& 5 for lower, middle \& upper stories respectively exhibit a very stiff response for $\mathrm{R}=3$, while for $\mathrm{R}=4 \& 5$, the decrease in the displacements is not significant.

Even the drift ratios are relatively less in the combined model for $\mathrm{R}=3$.

In the combined models with columns chosen from the basic models designed for $\mathrm{R}=3,4 \& 5$ for the lower, middle \& upper stories respectively much lower displacements and storey drifts for $\mathrm{R}=3$, again are observed and not so much for $\mathrm{R}=4 \& 5$.

Therefore in general, it can be said that the combined models defined in present work can be considered as optimum in lower zones where we consider $\mathrm{R}=3$ and not so much for higher zones where $\mathrm{R}=4 \& 5$

\section{PUSHOVER ANALYSIS}

Pushover analysis has given an idea how the combined model behaves in the inelastic regime. It is seen that the ductility demand is reduced in the combined model.

\section{EXPENDABLE TOP STORY}

It is seen that by a proper design of the top storey, it is possible to absorb the energy in the top storey, thus leaving the bottom stories to be within the elastic limits.

\section{Recommendations for further work}

It is recommended that further research be undertaken in following areas

1. Determining the optimum earthquake response of tall building structures by combining both optimized columns and beams.

2. Determining the optimum earthquake response of tall building structures by doing non linear dynamic analysis to assess the exact performance of combined model.

3. The ductilities obtained in the present work are the global values and thus may not help much in designing the members. Therefore a detailed analysis has to be performed to obtain the members ductilities.

\section{Application}


The method of combining the various structural elements from the basic models designed with different values of $\mathrm{R}$ is a simple method to obtain a frame which could be optimum, resulting in lower displacement and storey shears.

\section{REFERENCES}

[1] kyriakos G Stathopoulos And Stavros A Anagnostopoulos, Inelastic Earthquake Response Of Buildings Subjected To Torsion ,12WCEE 2000,PP0781

[2] Wilfred D Iwan, Ching-Tung Huang And Andrew C Guyader, Important Features Of The Response Of Inelastic Structures To Near-Field Ground Motion, 12WCEE 2000,PP-1740

[3] B. Borzi And A. S. Elnashai, Assessment Of Inelastic Response Of Buildings

[4] Using Force- And Displacement-Based Approaches, Struct. Design Tall Build. 9, (2000), PP-251-277

[5] Srinivas \& Bharatha, A Study On Inelastic Response Of Multi-Storey Buildings To Near-field Ground Motions, Report no-G22189, Dec-2007.

[6] Xiao-Kang Zou And Chun-Man Chan, Seismic Drift Performance-Based Design Optimization Of Reinforced Concrete Buildings, 13th World Conference on Earthquake Engineering Vancouver, B.C., Canada,August 1-6, 2004,Paper No. 223.

[7] B. Ganjavi \& H. Hao, An Optimization Technique For Uniform Damage Distribution In Inelastic Shear Buildings Considering Soil-Structure Interaction Effects, 15WCEE lisboa.

[8] Jian Zhang; and Wang Xi, Optimal Nonlinear Damping for Inelastic Structures Using Dimensional Analysis, 20th Analysis and Computation Specialty Conference, Structures Congress 2012

[9] B.K.Raghu Prasad, A.Seetha Ramaiah \& A.K.Singh, thesis on the capacity spectrum for structures asymmetric in plan, (2004)

[10] K.S.Jagadish and B.K.Raghu Prasad, thesis on The inelastic vibration absorber subjected to earthquake ground motions, (1979)

[11] B.K.Raghu Prasad and Jagadish (1989), thesis on the inelastic torsional response of a single framed structure.

[12] IS 1893(Part1): 2002."Criteria for Earthquake Resistant Design of Structures", Bureau of Indian Standards, New Delhi, 2002.

[13] IS 456 - 2000 "Code of practice for plain and reinforced concrete".Bureau of Indian standards, New Delhi.

[14] IS 875 Part 1 "Code of practice for Unit weight of material".

[15] IS 875 Part 2 "Code of practice for Live loads"

[16] "Seismic evaluation and Retrofit of concrete Buildings", ATC-40.
[17] Federal Emergency Management Agency (FEMA), 1997, NEHRP Guidelines for the Seismic Rehabilitation of Buildings, FEMA-273. 